\title{
Correlation of NS1 Antigen Positivity Performed by Immunochromatographic (Rapid Card Test) with Collection of Blood during First Week of Fever in Clinically Suspected Cases of Dengue Patients in a Tertiary Care Medical College Hospital
}

\author{
Dr. Shreeram Astic Deshpande*, Dr. Lavanya, Mr. K Gnanaprakash
}

Associate Professor, Department of Microbiology, Karpagam Faculty of Medical Sciences and Research, Othakkalmandapam, Coimbatore

DOI: $10.36348 /$ sipm.2020.v05i10.003

| Received: 05.10.2020 | Accepted: 19.10.2020 | Published: 23.10.2020

*Corresponding author: Dr. Shreeram Astic Deshpande

\section{Abstract}

NS1 antigen, known as Non Structural antigen is an important antigenic component of Dengue Virus. Dengue virus is transmitted by bite of Aedes aegyptii mosquito. Hemorrhagic manifestations and shock syndrome are most dreaded complications of Dengue IgM antibody is produced in acute phase and IgG in later phases of Dengue and may remain for very long periods.

Keywords: NS1 Antigen, Aedes aegyptii mosquito, Shock syndrome.

Copyright @ 2020: This is an open-access article distributed under the terms of the Creative Commons Attribution license which permits unrestricted use, distribution, and reproduction in any medium for non-commercial use (NonCommercial, or CC-BY-NC) provided the original author and sources are credited.

\section{INTRODUCTION}

Dengue fever is transmitted by bite of Aedes aegyptii mosquito. This mosquito bites during day time and has white stripes on its legs. The saliva of biting mosquito has infective form of virus which is transmitted during blood meal. Dengue is a mosquitoborne disease affecting humans mainly in tropical and subtropical regions of the world [1]. It is an increasing public health concern in urban and suburban areas causing severe morbidity and mortality [2-4]. Globally, WHO has estimated that around 3 billion people reside in areas where there are risks of exposure to dengue virus and nearly 50 million people are infected with dengue virus every year [5-7]. Dengue virus is a RNA virus, consisting of four serotypes (1,2,3 and 4) all of which cause infection. Infection with one serotype does not confer cross-protection against the other serotypes, instead can cause a severe form of infection [1]. Recently a fifth serotype was identified [8]. Early diagnosis plays a crucial role in detecting an epidemic or outbreak and in undertaking effective vector control measures [9].

\section{MATERIALS AND METHODS}

A comparative analysis of Serology samples collected for NS1 antigen by Rapid card test for the period from June 2017 to December 2017 in Department of Microbiology, Central services laboratory of Karpagm Faculty of Medical Sciences and Research, Othakalmandapam, Coimbatore was made with date of sample collection from clinical history and date of development of fever as mentioned in clinical history given by patient.

Blood sample collected was sent to Serology where after centrifugation it was used in Rapid card test using Immunochromatographic test for NS1 antigen.

Results: A total of 120 samples of Blood collected from suspected cases of Dengue with symptoms of Fever during the period from June 2017 to December 2017 formed the basis of study. Samples studied included from age group between 7 years and 60 years. Immunocompromised patients and infants were excluded from this study group.

Age wise positivity for NS1 antigen (Table 1), Sex wise percentage of Ns1 Positivity (Table 2) and Period of sample collection since development of fever with NS1 positivity (Table 3 ) were the main parameters of study. 
Table-1: Age wise distribution of NS1 antigen Positive cases.

\begin{tabular}{|l|c|}
\hline Age & NS1 antigen positive \\
\hline $11-20$ years & 40 \\
\hline 21- 40 years & 54 \\
\hline 41-60 years & 26 \\
\hline
\end{tabular}

Table-2: Sex wise distribution of NS1 Positivity

\begin{tabular}{|l|l|l|l|}
\hline Males & NS1 positive $(\&)$ & Females & NS1 positive (\%) \\
\hline 65 & $54.1 \%$ & 55 & $45.8 \%$ \\
\hline
\end{tabular}

Table-3: Period of Sample collection and NS1 Positivity

\begin{tabular}{|l|c|c|}
\hline $\begin{array}{l}\text { Period of Sample collection } \\
\text { (First symptom of Fever }\end{array}$ & Samples analysed & NS1 Positivity \\
\hline $1^{\text {st }}$ Day of Fever & 20 & 19 \\
\hline $2^{\text {nd }}$ to $5^{\text {th }}$ day of fever & 20 & 17 \\
\hline $1^{\text {st }}$ week of fever & 20 & 15 \\
\hline $10^{\text {th }}$ day of fever & 20 & 10 \\
\hline Beyond 12 days of fever & 20 & 5 \\
\hline Beyond 15 days of fever & 20 & 0 \\
\hline
\end{tabular}

Statistical analysis used to study was $\mathrm{P}$ value $(<0.05$ was significant $)$

\section{DISCUSSION}

Dengue fever known as " Swaheli Ka Denga Pepo" meaning sudden seizure by Demon, is also known as Break Bone fever. In extreme conditions it may lead to Shock syndrome.

Epidemics of dengue infection are showing an increasing trend in recent years. To date, there is no specific treatment for dengue virus infection. However, early diagnosis will help in the timely implementation of appropriate treatment, thereby greatly improving the outcome of the disease and also for effective public health control of dengue outbreaks [7, 10]. There are various methods available for diagnosis of dengue virus infection. Virus detection by tissue culture and immunofluorescence gives definitive identification of the dengue virus serotype. Virus isolation, even though considered the "gold standard" for the diagnosis of dengue infections, requires early acute sample (0-5 days post onset), requires expertise and appropriate facilities, time-consuming, expensive and laborious [15]. NS1 antigen detection is a useful tool for initial and early diagnosis of Dengue and this helps the patient and prevents them from landing in Shock syndrome (12, 13).

The Current study shows a very strong correlation between Period of sample collection since the development of fever and NS1 positivity by card test. For making a better statistical analysis and correlation, only 20 samples were selected based on duration of fever obtained from clinical history. It is evident from this study that as days progressed since the development of fever, NS1 antigen positivity rate dipped.

\section{CONCLUSION}

Dengue remains an Escalating problem all over the world but especially in Tropical Countries (11, 14).There is a severe impact on economy, morbidity and mortality in Developing countries which are located in the Tropics (15).

\section{REFERENCES}

1. Chua, K. B., Mustafa, B., Wahab, A. A., Khairul, A. H., Kumarasamy, V., Mariam, M., \& Rasid, A. K. (2011). A comparative evaluation of dengue diagnostic tests based on single-acute serum samples for laboratory confirmation of acute dengue. The Malaysian journal of pathology, 33(1), 13.

2. WHO. (2012). Dengue haemorrhagic fever: diagnosis, treatment, prevention and control. $2^{\text {nd }}$ edition. Geneva: World Health Organization. WHO [cited 2012 May 6]; Available from: http://www.who.int/csr/resources/publication s/dengue/Denguepublication/en/

3. Gubler, D. J., \& Meltzer, M. (1999). Impact of dengue/dengue hemorrhagic fever on the developing world. In Advances in virus research, 53, 35-70. Academic Press.

4. Tang, K. F., \& Ooi, E. E. (2012). Diagnosis of dengue: an update. Expert review of anti-infective therapy, 10(8), 895-907.

5. Kassim, F. M., Izati, M. N., TgRogayah, T. A., Apandi, Y. M., \& Saat, Z. (2011). Use of dengue NS1 antigen for early diagnosis of dengue virus infection. Southeast Asian J Trop Med Public Health, 42(3), 562-9.

6. Lee, J., Kim, H. Y., Chong, C. K., \& Song, H. O. (2015). Development and clinical evaluation of a highly accurate dengue NS1 rapid test: from the preparation of a soluble NS1 antigen to the 
construction of an RDT. Diagnostic microbiology and infectious disease, 82(2), 128-134.

7. Shrivastava, A., Dash, P. K., Tripathi, N. K., Sahni, A. K., Gopalan, N., \& Rao, P. L. (2011). Evaluation of a commercial dengue NS1 enzymelinked immunosorbent assay for early diagnosis of dengue infection. Indian journal of medical microbiology, 29(1), 51.

8. Peeling, R. W., Artsob, H., Pelegrino, J. L., Buchy, P., Cardosa, M. J., Devi, S., ... \& Halstead, S. B. (2010). Evaluation of diagnostic tests: dengue. Nature Reviews Microbiology, 8(12), S30S37.

9. Bhatt, S., Gething, P. W., Brady, O. J., Messina, J. P., Farlow, A. W., Moyes, C. L., ... \& Myers, M. F. (2013). The global distribution and burden of dengue. Nature, 496(7446), 504-507.
10. Kassim, F. M., Izati, M. N., TgRogayah, T. A., Apandi, Y. M., \& Saat, Z. (2011). Use of dengue NS1 antigen for early diagnosis of dengue virus infection. Southeast Asian J Trop Med Public Health, 42(3), 562-9.

11. Datta, S., \& Wattal, C. (2010). Dengue NS1 antigen detection: A useful tool in early diagnosis of dengue virus infection. Indian journal of medical microbiology, 28(2), 107.

12. RV, G. (2002). Vaughn DW. Dengue: an escalating problem. Bmj, 324(7353), 1563-6.

13. Gubler, D. J., \& Meltzer, M. (1999). Impact of dengue/dengue hemorrhagic fever on the developing world. In Advances in virus research (Vol. 53, pp. 35-70). Academic Press. 